\title{
William Ricketts: Peacekeeper on the Town Frontier, 1896-1922*
}

\section{Linda Ricketts Neal}

IN 1896 THE AMES CITY MAYOR appointed William A. Ricketts to the position of town marshal. In his subsequent law enforcement career which spanned the first two decades of the twentieth century, William Ricketts alternated between serving as Ames' marshal and the sheriff of Story County. The story of Ricketts' successful attempts at maintaining law and order in the central Iowa community provides an interesting look into small town society at the turn of the century. Like countless other law officers in the small towns scattered abundantly throughout the Middle West, Ricketts performed a vast array of community functions, above and beyond his legal responsibility of law enforcement. During a long and distinguished career, Officer Ricketts was known not only for his imposing appearance and his unrelenting firmness but his kindness and understanding as well. At the time of his death, the inmates of the Story County Jail revealed their respect for this man when they submitted a letter to the Nevada Evening Journal (September 20, 1922) stating that "the county has lost a good officer and we have lost a good friend."

Ricketts was born near Coshocton, Ohio, on January 5, 1867. He came to McCallsburg, Iowa, in 1881 and lived with a sister until he married Lillie Belle Smith from Ames in September of 1886. Following an unsuccessful attempt at farming in Warren

*The account of William Ricketts' service as town marshall and sheriff was reconstructed largely from articles in the Ames Times, renamed Ames Evening Times in 1912. That paper joined with the Ames Tri-Weekly to become the Ames Daily Tribune in 1919. The author thanks Dorothy Schwieder for her guidance and encouragement in preparing this article. 
Township, the couple moved to Ames. Ricketts was soon discovered by Mayor Henry Wilson and received his first star as town marshal on January 10,1896 . Typical of small town law enforcement officers of the day, Ricketts had no special training for his job as marshal. Nevertheless, the strapping six foot, 250-pound marshal carried out his duties successfully as evidenced by the title, "Big Bill," a sobriquet affectionately given him by his satisfied constituents. Big Bill served as marshal of Ames' one-man police force from 1896 to 1903 and again from 1910 to 1916 . During the interim period, Story County voters elected him as their sheriff in 1903, and he remained in this position until 1909. Officer Ricketts was reelected to this office in 1919, and was the Story County Republican Party's incumbent candidate for sheriff at the time of his death on September 18, 1922.

Ames was still a relatively young community in 1896 . Founded in 1864 , its growth was aided considerably by the Cedar Rapids and Missouri Railroad (later the Chicago and Northwestern) locating a depot there. In the early 1890 s, Chicago and Northwestern officials converted the line through Ames into a double track, and the city limits were extended to include Iowa State Agricultural College. By 1900, Ames residents could claim a population of 2,422 . The railroads provided the impetus for growth in other communities of the county as well, with the Milwaukee Railroad passing through the southern part of Story County and the Iowa Central crossing through the northern section. At the time William Ricketts became sheriff in 1904, the population of Story County had reached $23,159 .{ }^{1}$

Big Bill's chief task as the marshal was that of peacekeeper. As he walked his patrol of the expanding city streets, Marshal Ricketts untangled brawlers, threatened bootleggers, apprehended thieves, and attempted to keep Ames' hobo population at a minimum.

The Ames City Jail was located next to the fire station on the corner of Fifth Street and Kellogg Avenue. The brick building contained only two cells and was heated in the winter by a potbellied stove. It was Marshal Ricketts' job to keep the stove going to

'W. O. Payne, History of Story County, Iowa, 2 Vols., (Chicago: S. J. Clarke Pub. Co., 1911) I: 24, 450. 
produce adequate heat for the jail. ${ }^{2}$

At times the small bastille could not hold all of the law breakers. On December 1, 1913, the Ames Evening Times reported the following:

The city will be compelled to enlarge the jail or call off Marshal Ricketts, judging from the manner in which he filled it up Friday evening. In fact he got it so full that he was compelled to give one of them his liberty. He had four in his custody at one time, and the jail is only built to accommodate two.

Two of the incarcerated individuals were recovering from "an oversized load" of liquor. One had suffered the unfortunate experience of tumbling to the railroad platform when the train he was riding, old Number Six, jerked to slow down. The marshal released a prisoner upon the latter's promise to appear before Mayor Parley Sheldon the next morning.

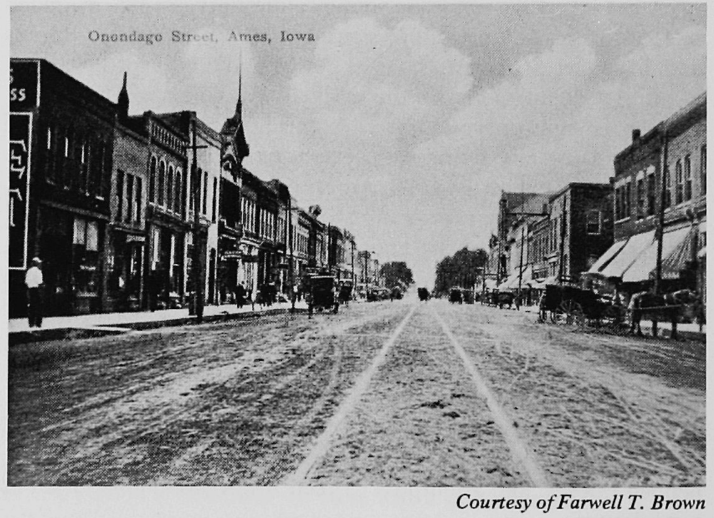

Main Street in Ames, 1908 (Onondago Street).

By 1915 , the city hall had "outlived its usefulness for a town of this size." The city council approved plans for a new city hall by an eleven to one vote. The Ames Evening Times reported: "the new structure is to be modern and up to date in every way." The

${ }^{2}$ Willard Myers, private interview, Ames, Ia., April, 1971; Letter, Gladys Kern to Linda Ricketts, May 4, 1971. 
old building was purchased by a local resident for $\$ 100$ and was out of the way by June, 1915.

The town needed a facility to house prisoners until the new jail was completed. Ames officials solved their dilemma by relocating the cells from the old jail behind the Odd Fellows building at $2251 / 2$ Main Street. This makeshift jail was to confine drunks, while the county jail would be used for any criminals picked up before the completion of the new city hall. The temporary quarters caused difficulties, however. City officials did not secure a covering for the cells, and hoboes and "backsliding" opportunists came into the town in larger numbers thinking that "they saw easy pickins' in Ames when the walls of the old city jail disappeared." By the evening of the first day of its use, six drunks and vagrants found themselves behind bars, but, because there was no cover, they were turned loose and walked out of town.

Ames officials sought a new solution to their problem by moving the cells into a corner of Kooser's Garage on Main Street and Burnett Avenue. The Ames Evening Times (June 2, 1915) commented that this location was better than the old jail itself because it had a cement floor and there was no danger of fire. In December, 1915, the town received a new steel cage destined for the new city hall which was to be installed and ready in a few days. The new cell for "booze men" would hopefully eliminate the problem of letting drunks roam the streets because of a lack of jail space. The new cage would accommodate twenty prisoners and would be "warm and sanitary."

Before 1914, prisoner life for "loitering gentlemen" usually involved some manner of grounds work or town improvement. While contributing their efforts to the beautification of Ames, these hobo prisoners were fitted with ball and chain shackles. In 1911 , six more sets of the shackles were purchased for the prisoners, which prompted the following comment in the Ames Times (April 11, 1911):

Hereafter whenever Marshal Ricketts, or any of his assistants pick up one of the loitering gentlemen he will be presented with a set of the pedal adornments, some street cleaning utensils, and a license permitting him to clean the streets of Ames.

Ricketts was the first marshall of Ames to bear the official title of City Marshal. The Ames Times referred to him as Chief of Police as early as 1911-the first to be called so by the newspapers 
in Ames-but the title was not officially recognized until 1928. Although the marshal from 1908 to 1910 had appointed deputies to assist him, "Chief" Ricketts was the entire police force in Ames until his resignation in 1916. Ricketts was also the first officer of the town to wear a police uniform, an outfit presented to him by the citizens of Ames "for bravery and general capability in office."

The post of city marshal gave Ricketts an assorted daily routine. In addition to handling drunks, he often filled in as the city dog catcher. In 1910 a mad dog scare forced him to destroy a number of dogs for the good of the town. Marshal Ricketts was also bearer of sad tidings in cases of death by accident-it was his duty to accompany the doctor to inform relatives of victims.

Hoboes were a frequent source of disruption to the peace of Story County at the turn of the century. The conversion of the Chicago and Northwestern line into a double track through Ames during Ricketts' first years as marshal brought a number of hoboes into the town. By 1911, hoboes were a constant menace, and it was in that year that Ames city officials added the six ball and chain shackles to discourage hobo loiterers.

Three years later the ball and chain penalty was no longer enforced, and by June, 1914, Big Bill had come to the end of the line with the hoboes in Ames. The tramps had "become a nuisance." The marshal arrived at a new plan which he hoped would rid the town of them. "Yesterday was a good day for thinking and Marshal Ricketts spent it in deep thought over the hobo question," the Ames paper reported. Ricketts' solution was "to give every hobo he could connect up with" a taste of his fists. According to the newspaper, that very morning the marshal encountered two "boes" begging in front of the Iowa Cafe and he reacted in the following manner:

[Ricketts] gave one a slap on the jaw he is probably thinking about yet. Both started east on Main street with the city police department in close pursuit. At Duff avenue they turned on to the railroad tracks and made the gravel fly.

The newspaper never commented as to the effectiveness of this plan in discouraging the hoboes from sojourning in Ames, but it did add this: "One contact with Marshal 'Bill's' fist will do the business though, and they will be glad to avoid a repetition of it."

In May of 1915, one hobo carried the dreaded smallpox 
disease into Ames. Marshal Ricketts diagnosed the case and hurried the man to a secluded spot until the proper authorities were located. The stockyards, where the man had slept, were fumigated. Later arrangements were made for his removal to a new city pest house at the sewage disposal plant lot on South Duff Avenue. This was the first case to be confined to the pest house. There were no more reports of smallpox in Ames during the next two months.

A trio of hoboes taken into custody in 1913 proved to be adept at thievery. Not only did they take the last three dollars from a fourth hobo in Ames, but while in custody they were discovered to be the same three who had robbed a railroad camp at Clinton. Robberies and thefts were common in Big Bill's time. Many of these involved criminals wanted in other parts of the state for similar offenses. Professionals were responsible for a robbery case handled by Ricketts on January 7, 1915. When the marshal arrived at a house on Lincoln Way to arrest two men in connection with the robbery of A. L. White's Hardware Store, "Their rooms resembled a small arsenal and they were evidently expecting a raid." One man was lying on a bed in the next room with a revolver near his hand. "In the room which Marshal Ricketts entered there was a large revolver lying on the table. Both guns were loaded and ready for instant use." The two men were immediately placed under arrest, and further search turned up missing flashlights from the hardware store.

A theft incident in 1910 proved to be one of Marshal Ricketts' most embarrassing moments as an officer. The Ames Times reported this story: "Question: Is Bill Ricketts, the genial city marshal of Ames a Good Samaritan or an Accessory?" In September a production entitled "The Queen of Beauty" was playing at the Armory in Ames, and one of the chorus girls in the early hours of the morning "chased around on Main street endeavoring to find a store open where she might buy a suit case. Going into the Judisch drug store, she spied the blue suit and bright star of the city marshal and scented sympathy." The girl, who was rooming at Gene Roll's, asked the marshal to call her at two o'clock so she could take her train. "Bill thought he'd better help her get off with her company and said, 'Why, I'll either call you or send the bus after you.' "At two o'clock Marshal Ricketts called the chorus girl and carried the overloaded suitcase to the station. The 
next morning Mr. Roll informed him that the chorus girl "had helped herself to part of Mrs. Roll's wardrobe." The affair resulted in Gene Roll going to Des Moines with an officer after the girl to get back the stolen goods "or their equivalent in money."

Horse thieves were a problem as late as 1913. In that year two horses, valued by their owners at \$200 each, were stolen. Marshal Ricketts immediately sent out cards with a description of the two animals to every county in the state and a notice of a $\$ 25$ reward. The thieves also took an old spring wagon and a Concord harness belonging to one B. B. Murphy. Marshal Ricketts thought the theft looked like the work of an organized gang which had been stealing horses around Des Moines all winter.

The automobile's rise in popularity was accompanied by a rise in reported car thefts. In 1914, a rather unusual theft took place concerning H. M. Duckworth's auto. The thief left the auto standing in its original location, minus two center coils, three inner tubes, and a set of mud chains. The equipment was valued at about $\$ 25$. It was speculated that the thief had an immediate use for the articles because nothing else was touched.

An incident which occurred in 1912 is reminiscent of a "keystone cops" episode. Mayor Jones of Marshalltown was charged with running his automobile on the wrong side of the street in Ames and striking General J. R. Lincoln's horse. The Ames Evening Times reported that "after striking the horse Jones did not stop to see what damage he had done but beat it down the street as fast as he could go." The paper concluded that "Jones was plainly in the wrong and will no doubt be assessed a fine by Mayor Sheldon."

A feature article in the Ames Evening Times of January 10, 1916, highlighting Bill Ricketts' twenty year career as a Story County officer of the law, described the marshal as "the head of Ames' thief and bootlegger takers." Bootlegging was such a menace to the town that by April of 1915 "Marshal 'Bill' Ricketts" had "declared war on the illegal transportation of liquor in suitcases and grips," and was determined to "clear out that sort of business in Ames." The March 23rd issue of the Ames Times announced, "Bootleggers Booted Out by Our 'Bill.' " In this case a quartet of men, hoping to get rich quick, set up a business of 
their own in the second story of a building owned by Captain K. W. Brown. Marshal Ricketts presented the four with a search warrant, seized a large supply of illegal liquor, and gave them twenty-four hours to leave the town.

In the early days of 1916, Marshal Ricketts was called on to quiet a group of men who were evidently still bringing in the new year. The Ames Evening Times (January 10, 1916) reported the incident in the following manner:

Starting in the new year at an astonishing clip the lips of which were nicely oiled by John Barleycorn, three boozeful individuals succumbed to the wiles of Big Bill Ricketts, city marshal, yesterday, and there was some contribution to the city treasury therefor.

They were singing in various chords "Bury Me On the Prairie" when the city law burst in upon the concert. It was in the "corn cribs," a favorite resof for knights of the bottle. They became so obnoxious that the neighbors gave it up in disgust and yelled for help.

Two of the three were assessed a fine of $\$ 5.85$, and a third was to "be hauled up tonight for judgement."

As conservator of the peace, Marshal Ricketts attended the Ames High School and Iowa State College athletic events. He positioned himself in a spot where his authority would be noted and where he could easily observe the game. His ability at handling the students enhanced community-college relations. The Ames Evening Times (January 10, 1916) described his ability thus:

The marshal has a happy faculty of handling obstreperous students, the ebullient youth who like to make the wolf howl, and in their more or less innocent celebrations, he always has a leading hand. His success in this line was instanced after the Iowa victory last fall, when he manipulated a joyous horde with the hand of a master and what might have developed into a disastrous night went by without any heavy splashes.

When Iowa State College won a football game, students marched downtown afterward and crashed a theater; Marshal Ricketts rode along with the students on the fire truck. He helped them pick up boxes in the back of stores for their victory bonfire. Big Bill became such a favorite of Iowa State students that the student body presented him with a billy club made of strips of leather and adorned with gold and red ribbons. ${ }^{3}$

When Ricketts became Story County sheriff in 1904, he took

${ }^{3}$ Bernice M. Ricketts, private interview, Iowa City, Ia., April, 1971; Letter, Gladys Kern to Linda Ricketts, March 17, 1971. 
on a larger area and population. His new job entailed a broader scope of duties. Thefts and robberies became his primary concern. He had to travel all over Iowa and out of state in pursuit of truant husbands and criminals-at-large. During a trip to the state penitentiary with a convicted criminal Sheriff Ricketts suffered an attack of ptomaine poisoning that slowly developed complications, and eventually took his life at the age of fifty-five.

In 1890 , Story County citizens sanctioned the building of a new county jail and sheriff's residence. This was the residence that Ricketts and his family occupied in Nevada during his terms in the county office. Like many other sheriffs' residences in counties throughout Iowa, the county prison formed the back part of the family home and was separated from the living area by two iron doors. The house was situated on the south end of the courthouse lawn. It was rather large, with an entry hall, living room, drawing room, bedroom, dining room, and big kitchen downstairs, and three bedrooms and a bath upstairs. The four cells in the rear of the house were just off the large sitting room and across from the kitchen. There was a large cell in the middle of this room with a box of levers which controlled the other cells. The women's ward was on the second floor above the men's prison. ${ }^{4}$

On the north end of the town square was the white brick county courthouse with its huge pillars standing before the front and back doors. Across the street from the Story County Jail was a two-cell city jail restricted to the patronage of the town's inebriated individuals. This small, gray building provided additional space for the sheriff when necessary.

The jailers along with the rest of the sheriff's force-deputies and bailiffs-were appointed by the sheriff and were under his personal direction. Ricketts served as jailer himself, receiving from the county a flexible amount of money for jail expenses. The amount for the board and laundry of prisoners during Ricketts' terms in office was $\$ 305.87$ in $1919, \$ 918.80$ in 1920 , and reached its peak in 1921 with a sum of $\$ 1,418.25$. Sheriff Ricketts did ap-

${ }^{4}$ Letter, Bernice M. Ricketts to Linda Ricketts, March 4, 1971; Letter, Gladys Kern to Linda Ricketts, May 4, 1971. Bernice M. Ricketts, private interview, Iowa City, Ia., April, 1971; Payne, History of Story County, Iowa, I, 439. 
point deputies to help him. One deputy, Ira Crooks, served as his appointed force until 1920, when Ricketts added his own son, Bill, Jr., as a second deputy. ${ }^{5}$

While Sheriff Ricketts was in his office at the county courthouse, his family looked after the prisoners' food and other needs. His wife prepared the meals and served them to the prisoners in long pans which were shoved through a little door in the kitchen wall. The family arrangement had its disadvantages, however. On one occasion Sheriff Ricketts returned home from a trip earlier than expected and prevented an escape attempt by the prisoners who intended to make their break when Mrs. Ricketts served the food to them. ${ }^{6}$

Young runaways and offenders, too, were given the benefits of Mrs. Ricketts' cooking. Big Bill was a "patsy" for young offenders, youngsters who had run away from home, stolen a car, or had been arrested for breaking and entering. He made it a point to ask the offender three questions: 1) Did he attend Sunday school? 2) Was his home life happy? 3) What prompted him to do this? More often than not the offender had not attended Sunday school, was from a broken home, and had just wanted a few nice things. If the young boy was alone in his cell, he would end up at the family table for supper, returning to his cell again for the night.

Much of the courthouse lawn work was done by the prisoners of the Story County Jail. Sheriff Ricketts made "trustees" of the prisoners he could trust and allowed them to do outside workthe yard work required on the courthouse block. The Ricketts children enjoyed working along with the trustees. It was a rare occurrence when one of these men would take flight, but once a trustee did walk off from his job early in the morning. By six o'clock that evening the man returned because he was hungry. Big Bill often remarked that his wife's good cooking had saved the day for him.

${ }^{5}$ William A. Jackson, The Office of Sheriff in Iowa (Cedar Rapids, Ia.: Torch Press, 1924), p. 36; "New Sheriff Moving Over," Nevada Representative, Dec. 30, 1918, p. 1; Story County, Ia., County Auditor, Financial Report of Story County. Iowa for the Years 1919-1922 (Collins, Ia.: Collins Gazette, 1920-1923); "Bill Ricketts Resigns," Nevada Representative, September 22, 1921, p. 1.

'Bernice M. Ricketts, private interview, Iowa City, Ia., April, 1971; Olive S. Ricketts, private interview, Iowa City, Ia., April, 1971; “New Sheriff Moving Over," Nevada Representative, December 30, 1918, p. 1. 
During Ricketts' first few terms as sheriff, Story County furnished him with a horse and buggy. The county allotted him mileage fees for his transportation: \$571.26 in 1904, \$630.75 in 1906, and $\$ 594.85$ in 1907 . During his second period as sheriff-19191922-Big Bill was given an automobile to drive. The Ford came equipped with isinglass windows which were attached to curtains that snapped into the moveable top. Between the restricted visibility of the isinglass windows and the sheriff's habit of talking with his hands while driving, the old car furnished many with an unwanted thrill.?

There were certain duties that Sheriff Ricketts did not like to perform, among which was calling people for jury duty. There was no secretary in his office, so the sheriff, a man not known for possessing a great deal of patience, had to do the calling himself. During the Cline-Hamilton murder trial of 1920 , Ricketts was handed a list of seventy-five prospective jurors to call. He was "compelled to stay at the telephone for six hours, while calls were given him by a special operator at the telephone office." ${ }^{8}$

The serving of eviction notices or attachment papers was another duty Sheriff Ricketts disliked. Ricketts carried out most of his tasks single-handedly, but he always wanted someone with him for this job. On one occasion he had to go to the north end of Nevada to serve an attachment on a woman's furniture. This was never carried out. Big Bill gave the woman $\$ 10$ and returned the paper to the county attorney. He informed the attorney that there were a number of justices of the peace in the county who would serve the notices, but, "I'm not going to." There was some discussion between the two men concerning the matter, but the sheriff stood firm; he did not serve the paper. ${ }^{9}$

One unofficial duty which Sheriff Ricketts initiated and happily performed from 1903 to 1909 made him a favorite among the children of Nevada on the Fourth of July. He personally super-

${ }^{7}$ Ivan Shalley, private interview, Nevada, Ia., April, 1971; Letter, Gladys Kern to Linda Ricketts, May 13, 1971; Story County, Iowa, County Auditor, Financial Report of Story County, Iowa for the Years 1904, 1906, 1907 (Maxwell, Ia.: L. R. Shepherd Publishing Co., 1905); Bernice M. Ricketts, private interview, Iowa City, Ia., April, 1971; Florence E. Ricketts, private interview, Ames, Ia., July, 1971.

${ }^{8}$ Letter, Gladys Kern to Linda Ricketts, March 24, 1971; “"Ricketts Is Busy When Men Called," Nevada Representative, Dec. 6, 1920, p. 1.

${ }^{9}$ Bernice M. Ricketts, private interview, Iowa City, Ia., April, 1971. 
vised the main feature of the celebration. Every year on this national holiday, Sheriff Ricketts would set off $\$ 10$ worth of fireworks on the courthouse lawn to entertain the children of the community. Big Bill and his fireworks were a regular feature of the Nevada Fourth of July celebration. ${ }^{10}$

Acting as the chief county law enforcing officer, Ricketts often found it necessary to travel across the state line in pursuit of wife deserters. One case led the sheriff to Tennessee armed with a requisition for a man who had deserted his wife and three children in Story County. The Nevada Representative commented that the "usually amiable sheriff was not in the best of moods" when he left for Tennessee since "he feared he was bringing Dawson back only to have the truant husband patch it up with his wife and escape the penalities of desertion." About $\$ 400$ in Story County expense money was paid to get the man out of Tennessee. ${ }^{11}$

From 1919 to 1922, reported stolen cars and driving violations were noticeably more common. In March of 1919 Sheriff Ricketts traveled to Des Moines to claim a stolen Ford from Nevada which had made its way to the capital city. In May, 1921 Sheriff Ricketts picked up a certain C. C. Montgomery from Nevada and charged him with operating an automobile while intoxicated. ${ }^{12}$

In June, 1919, another type of theft took place. In spite of the growing popularity of the automobile, the value of a good horse was still quite high, and at least one thief had calculated this for himself. He took off with a team of horses from the Aulgar Brothers' "Tenderfoot" Company Show. The theft was discovered when laborers were tearing down the show and loading the production's special cars. The search was carried three and a half miles northwest of the town of Nevada where the horses were found. Sheriff Ricketts was fairly certain that the thief was some-

${ }^{10}$ Florence E: Ricketts, private interview, Ames, Ia., July, 1971.

"1"Ricketts After Wife Deserter," Nevada Representative, Aug. 4, 1921, p. 1; "Wife Deserter Freed by Jury," Nevada Representative, Sept. 6, 1921, p. 1.

${ }_{12}$ "Stolen Ford is Recovered," Nevada Representative, Mar. 27, 1919; "Montgomery Is Arrested Today: Will Give Bond," Nevada Representative, May 10, 1921, p. 1. 
one living in the area where the team was found, because "he must have been acquainted with the way to get in and out of the pasture." 13

The account of a county murder unfolded in 1920, and the quick arrest of the suspects and their subsequent admission of guilt was attributed to "Sheriff William A. Ricketts . . . for his speedy work, along with State Agent Yackty, of Des Moines." 14 The actual crime was reported as follows:

James Hamilton, farm hand employed on the Fred Kargers farm and Roy Cline, Nevada drayman, killed Andrew Jorgenson, hermit, at his farm north of the county farm Tuesday night. They got an old Elgin watch and $\$ 14$ cash for the crime.

Immediately after they left Jorgenson, bound and dying in his dooryard two more robbers came upon the scene. . . These two men, sheriff Ricketts declares, are Fred Berry and Fred Clark, both of Nevada. ' s

Shortly after the arrests of Cline and Hamilton, Sheriff Ricketts issued a statement to the Nevada Representative explaining the events leading up to the arrests. Ricketts explained how he discovered the crime after a telephone call informed him that a man had been found dead: "When I saw Jorgenson lying face downward on the ground, I knew something was wrong, and that it was not accidental or sudden death." Almost before the coroner's jury's verdict had been reached, Ricketts learned of a man who had approached residents in Cambridge to join in a robbery such as the one that took place. Working on the tip, Sheriff Ricketts arrested Berry and Clark. "We talked to them all night . . ." Cline and Hamilton were then arrested. "Hamilton was brought to town. He denied he was implicated. One half-hour later, however, he admitted the crime in its entirety." Hamilton had hit Jorgenson twice with a gas pipe before seizing his money box. "In the box was a deposit slip for $\$ 1,034$ deposited on the day Jorgenson was killed." Ricketts added this: "The men claim they told their wives what they were going to do and what they had done. This the wives deny. I believe the women." 16

Hamilton and Cline were bound over to the grand jury without

${ }^{13}$ "Thief Steals Show Horses," Nevada Representative, June 5, 1919, p. 1.

${ }_{14}$ "Cline and Hamilton Held without Bond for Andrew Jorgenson Murder," Nevada Representative, Oct. 28, 1920, p. 1.

15 "Story Murderers Confess," Ames Daily Tribune, Oct. 26, 1920, p. 1.

${ }^{16}$ William A. Ricketts, "Story County Sheriff Tells How Cline-Hamilton Caught," Nevada Representative, Oct. 28, 1920, p. 1. 
bond by Mayor C. A. Batman, and were charged with the murder of Andrew Jorgenson at his farm home on October 19th. One reporter commented in the Ames Daily Tribune (October 28, 1920 ) that "Hamilton and Cline maintained their calm when they were brought before Mayor Batman." The reporter continued with the following comments:

While the information, signed by Sheriff William Ricketts, was read, they looked at him. However, several times when the word murder was spoken and Andrew Jorgenson was named, Hamilton trembled slightly and dropped his eyes to the floor. Cline was unperturbed and sat thru the hearing with perfect calmness.

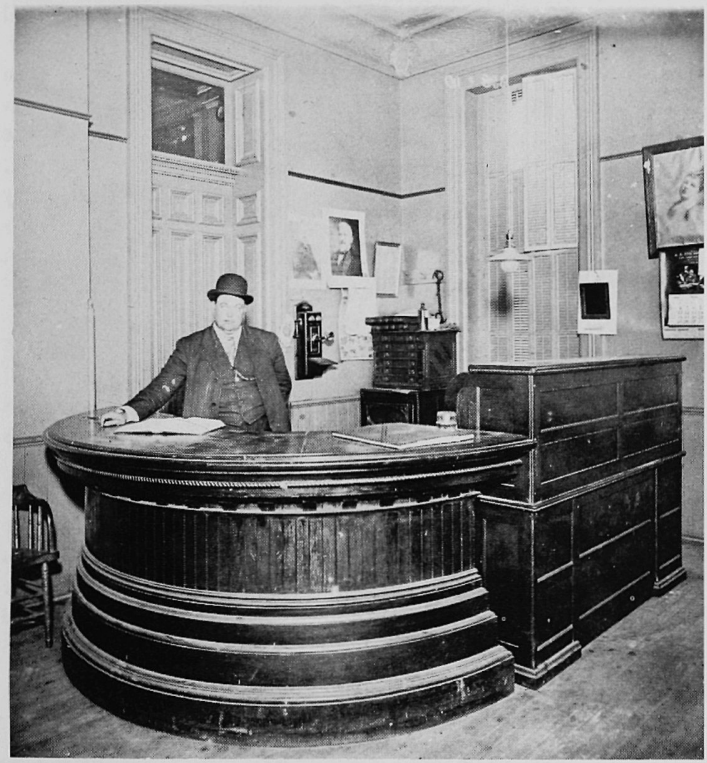

Courtesy of Mrs. Bernice M. Ricketts

William Ricketts in his office at the County Courthouse in Nevada, 1907. 
Cline and Hamilton were given sentences of life imprisonment for the murder of Jorgenson. On December 8, 1920, Sheriff Ricketts prepared to leave for the state penitentiary at Fort Madison with Cline, Hamilton, Berry and Clark. It was his duty to deliver them to the penitentiary where they would serve out their sentences.

Story County was not without scandalous incidents in the early twentieth century. In the first decade and a half of the twentieth century, the newspaper applied the term "serious charge" to sex crimes. By the middle of the second decade this terminology was changed to read "social crime." Hence, when in 1921 two boys were held for enticing a fifteen year old girl into the local Ames hotel, the headline of the story in the Nevada Representative (January 3,1921) read, "Two Held for Social Crime." In an earlier time, the headline of an adultery story in the Ames Times (January 11, 1912), in which the accused man was found by the husband upon the latter's return home after a few days' absence, read "Arrested on a Serious Charge." In this case the third party claimed he was merely visiting on a social call, but the irate husband, refusing to believe him, took after him with a shotgun. Marshal Ricketts was called into the matter and escorted the accused party to the Story County Jail in Nevada.

The pay involved in Big Bill's job as the "head of the Ames Thief and Bootlegger Takers," murder detective, and handler of the "ebullient youth," changed a great deal over the years of his service. When he was first hired in 1896, Marshal Ricketts was paid the total of $\$ 10$ a month. By March of 1916, the amount had increased to $\$ 960$ a year. When Marshal Ricketts first became Sheriff Ricketts in 1904 , he was paid $\$ 1,800$ a year plus a mileage fee. In 1915, the fee basis of the sheriff's office was changed to a salary basis which was set according to the population of the county, and in 1919 Ricketts' salary was set at $\$ 1,901.92$ with extra funds for postage $(\$ 28.50)$ and miscellaneous expenses $(\$ 28.40) .^{17}$

'Mrs. Richard K. Bliss, "Ames History, 1894-1903," in Ames Community History (Ames, Ia.: Ames Centennial, Inc., 1964), p. 64; Ames, Ia., Department of Finance and Municipal Accounts, Official Report, for the Fiscal Year ended March 31, 1916 (Ames, Ia., 1916), p. 20; Story County, Ia., County Auditor, Finanical Report of Story County, Iowa, for the Years 1904, 1919 (Maxwell, Ia.: L. R. Shepherd Publishing Co., 1905; Collins, Ia.: Collins Gazette, 1920); Jackson, The Office of Sheriff in Iowa, pp. 12, 19. 


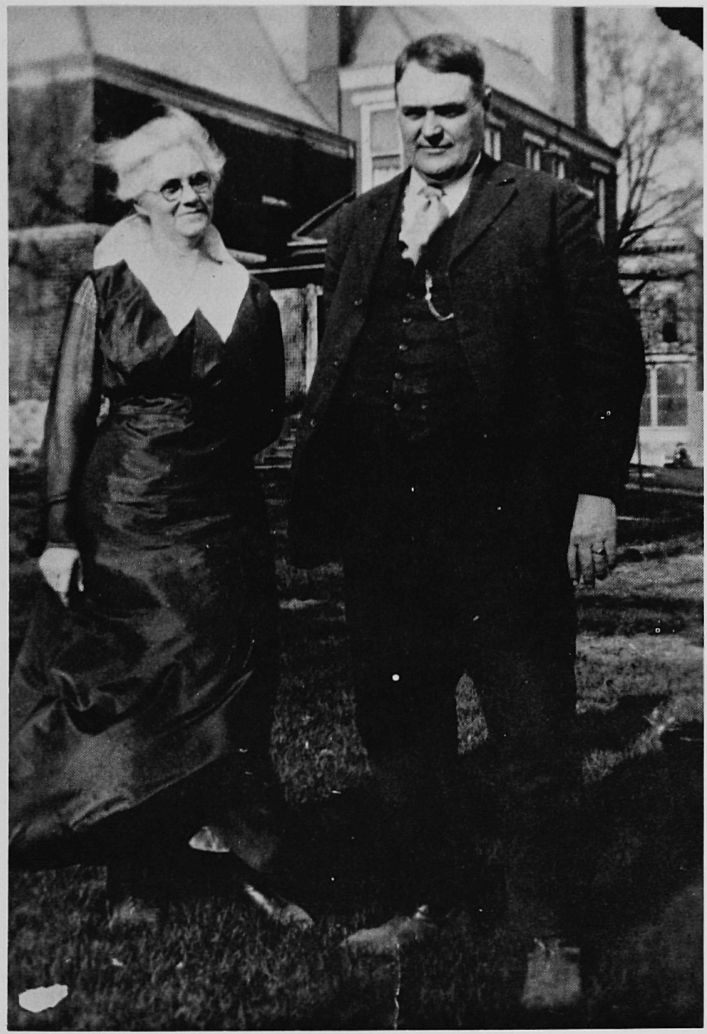

Courtesy of Mrs. Bernice M. Ricketts

William Ricketts and his wife, Lillie Belle, standing in front of the jailhouse in Nevada, circa 1920. 
The Nevada Evening Journal (September 18, 1922) called Sheriff Ricketts "one of the most popular peace officers in the state and his acquaintance was wide over the state where he was recognized as a daring and fearless officer." Ricketts was a figure of stability in the Ames community. He conserved the town's peace-he preserved the status quo-and he did so "fearlessly" and "justly." Big Bill's large frame was an advantage to his job as officer of the law. His size alone suggested authority. Yet, as one article noted, "his heart was just as large as his body in proportion." The thing that made him so great was his love of mankind and his unusual sense of humor." Big Bill "was always considered a friend of the people." He "gave the impression of feeling good and liking everybody." However, Officer Ricketts "didn't like strangers coming in and mooching off the people-beggars and the like. He set them on their way in a hurry." 18

William A. Ricketts lived in a world of transition. The optimistic progressivism which initiated the new century was shattered with the coming of World War I. Then the nation plunged into the sensationalism of the twenties. The press in Story County echoed this sensationalism in the newspaper accounts of the 1920 Jorgenson murder.

To law enforcement officers located in the small towns throughout the Midwest, the first two decades of the twentieth century were years of bootleggers, transients, panhandlers, thieves, wife deserters, amazing accidents, and senseless murders. In this accident prone, rapidly changing world, William A. Ricketts, like so many other peace keeping officials, served as a symbol of stability.

${ }^{18}$ Letter, Gladys Kern to Linda Ricketts, March 17, 1971; Willard Myers, private interview, Ames, Ia., April, 1971; Clark Tilden, private interview, Ames, Ia., April, 1971; "Ricketts Funeral This Afternoon," Nevada Evening Journal, September 20, 1922. 
Copyright of Annals of Iowa is the property of State of Iowa, by \& through the State Historical Society of Iowa and its content may not be copied or emailed to multiple sites or posted to a listserv without the copyright holder's express written permission. However, users may print, download, or email articles for individual use. 